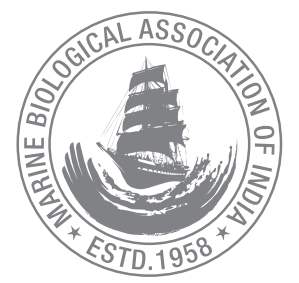

\title{
Gender Mainstreaming in Women SHGs through Seafood Kitchens in Kerala: An Appraisal
}

\author{
V. P. Vipinkumar*, R. Narayanakumar, C. Ramachandran, Reshma Gills, N. K. Harshan, \\ P. V. Athira, Annmary Jephi, G. Dhanya, S. Shalumol and P. Dona \\ ICAR- Central Marine Fisheries Research Institute, PB No: 1603, Ernakulam North P. O. Kochi- 682 018, Kerala, India. \\ *Correspondence e-mail: vipincmfri@gmail.com
}

Received: 11 July 2018 Accepted: 25 Jan 2019 Published: 30 Jan 2019

Original Article

\begin{abstract}
An appraisal on the impact of SHGs in gender mainstreaming was undertaken on the seafood kitchen units operating at Pooyya of Thrissur District and Pookode of Wayanadu District in Kerala. Performance assessment of the SHGs, gender analysis, empowerment analysis and economic feasibility analysis were carried out based on socio-economic surveys and personal interviews using pre-tested and structured data collecting protocols with standardized scales and indices involving the members of the SHGs. The quantification of empowerment Index was done based on 8 relevant dimensions constituting it. The male and female counterparts of the families were separately interviewed to assess the gender mainstreaming aspects in terms of equity and equality to resource access, participation profile, decision making aspects, gender need analysis etc. The scales standardized for Empowerment Index' and 'Performance Assessment' for this study have ample potential for future use in other key areas on a sustainable basis. The lacunae identified in computation of Empowerment Index give distinct feedback to authorities to proceed in the right direction. The gender dimension analysis on mainstreaming aspect gives sensitization on crucial issues like women fisher folk's rights and marketing channels for policies and other interventions on gender. Inter relationships between the variables measured in the study can act as catalytic points for group empowerment on a sustainable basis. The indicative
\end{abstract}

economics worked out for the economic feasibility analysis of the SHGs suggests that, the unit takes three years to break even. A success story was elucidated and documented as a video documentary which can be used as a practical manual and case model for promoting group action for mobilizing SHGs on a sustainable basis.

Keywords: Self-help group, Empowerment index, gender mainstreaming, performance level

\section{Introduction}

The paradigm of 'Gender Mainstreaming' essentially focuses on assessing the implications for women and men of any planned action, including legislation, policies or programs, in all areas and at all levels. It is simply a strategy for making women's and men's concerns and experiences as an integral dimension of the design, implementation, monitoring and evaluation of policies and programs in all political, economic and societal spheres, 
so that women and men benefit equally and inequality is not perpetuated. The ultimate goal is to achieve gender equality and equity which aims to transform the mainstream at all levels to end gender discrimination. Equity is the 'means' and equality is the 'result'. Equality is rights based in such a way that, women and men have equal rights, enshrined in international standards and treaties and should have same entitlements and opportunities. Equity means justice so that resources are fairly distributed, taking into account the different needs of women and men (FAO, 2017). Here in the present study, an attempt was made on the assessment of impact of SHGs in seafood kitchen units in gender mainstreaming in two districts namely Thrissur and Wayanadu in Kerala, India. The women mobilised venture of seafood kitchen through SHGs was promoted by Society for Assistance to Fisherwomen (SAF) of the Department of Fisheries, Kerala.

Poyya gram Panchayat is situated in Kodungallur Taluk of Mala Block of Thrissur District in Kerala, India. The panchayath office is situated in Pooppathy and Poyya is in the border of the Thrissur and Ernakulam districts. Here the tasty food items prepared by 'Amma sea food kitchen' welcome both foreigners and nationals. Under the direction of SAF and Agency for Development in Aquaculture, Kerala (ADAK), this unit was established in 2015 in Poyya Neithal Heritage Village which is an exemplary example of women empowerment through mobilised Self Help Groups. In this group, SAF implemented a holistic approach which increases confidence and hope among fisherwomen. With financial assistance from SAF, a small shop was first started by 'Neithal', a group consisting six women members and now it is an enterprise which can provide job to eleven women. Besides quality, tasty preparations using pearl spot, prawn, crab, anchovies, squid, clam, mackerel etc. are the major specialties of Amma sea food kitchen. A master plan has been submitted to the State Government to develop the model shrimp farm and training centre at Poyya, near Thirssur, as an aqua tourism spot. The fisheries museum set up showcase age-old fishing methods, including fishing crafts and gears. Rearing of prawns, crabs, milkfish and pearl spot in the farm ponds have also been planned and the fish grown in the farm is used to prepare traditional cuisine for tourists visiting the farm.

Like in Thrissur, SAF has enunciated another sea food kitchen near Pookode Lake in Wayanadu which was put forward for the upliftment of scheduled caste women fisherfolk. It is a success story of 12 women's unity with divergent and traditional delicious food of Wayanadu with specially prepared fish items. The scenic beauty of Wayanadu forest, the exciting voyage through the Pookode Lake, the aquarium with fresh water ornamental fishes and the fish spa are the major experiences, a traveler can derive from the seafood kitchen site at a nominal cost. This is a joint program of Department of Fisheries and Forest Department, Kerala.

The basic motive behind seafood kitchen envisaged by SAF is to utilise the cooking expertise of women fisherfolk which ensures a sustainable income though the cafeteria. The amount fixed for a group of 6 members of SHG is 6 lakhs provided in 3 installments. First installment is $80 \%$ of the fixed capital and the rest two after close scrutiny of the utilisation of the amount. Of this, the amount beyond $80 \%$ was included as bank loan $(15 \%)$ and beneficiary contribution (5\%). For the bank loan, SAF also provides approximately $12 \%$ every year interest free credit support. The total budget comes to around 10 lakhs. There are 5 seafood kitchens in Kerala and the other three districts are Kozhikode, Alappuzha and Kollam.

\section{Material and methods}

With the assistance of SAF, the research team of Central Marine Fisheries Research Institute (CMFRI) visited the Poyya and Pookode locations once in a month for five times and conducted interaction program for the fisherfolk on seafood kitchen units. A series of farmer interaction meetings were organized for these SHGs. The assessment of participation profile, decision making, gender need analysis, economic feasibility analysis etc. also were undertaken by interviewing the men and women counterparts of the families of the SHG members. A map showing the locale

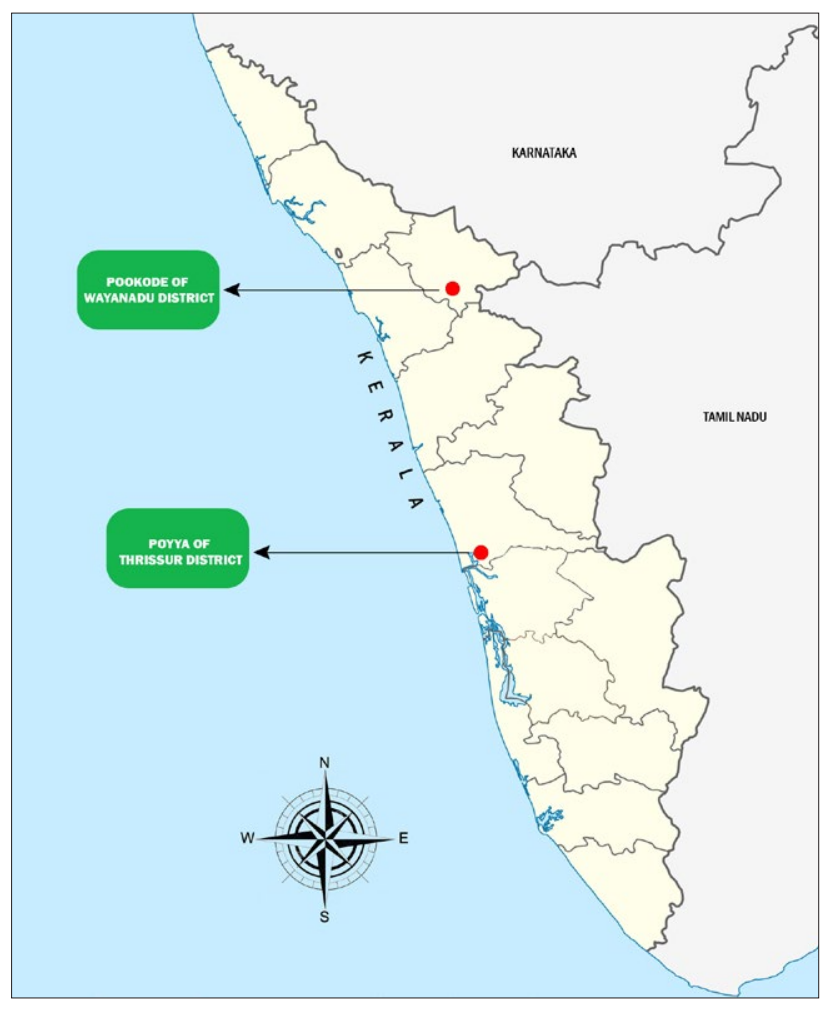

Fig. 1. Map of Kerala showing the locale of the study 
of the study ie. Poyya, Thrissur District and Pookode, Wayanadu District, Kerala is presented as Fig. 1.

The major aim and methodology employed essentially consist of practical extension coupled with extension research. The study was undertaken with the major objectives to organize awareness and capacity building programs of Entrepreneurial Capacity Building (ECB) in cooking and mobilizing resources for seafood kitchen technology covering the practical extension part. The objectives covering the research part included the assessment of impact of SHGs in gender mainstreaming which was undertaken through assessment of the performance level of SHGs and Empowerment Index through appropriate scales and indices and gender analysis of the members of SHGs of seafood kitchen units. An attempt was also made to document a success case study of these SHGs in Poyya and Pookode as a video documentary which can be used as a practical manual for mobilizing similar SHGs in any key areas on a sustainable basis.

The practical extension part focused on awareness \& $E C B$ Training programs on empowerment and motivation with systematically executed farmer interaction meetings in Poyya and Pookode with the involvement of scientists from CMFRI and SAF officials. Stage by stage Video documentation of the various phases of activities of SHGs in seafood kitchen units was also undertaken.

The extension research part focused on socio economic surveys with a pre-tested and structured data gathering protocol consisting of standardized scales and indices to assess the impact of group approach in enhancing their standard of living. The involvement of people in site selection, purchase of accessories, arrangement of raw materials and other inputs, cooking, serving, cleaning, marketing, arrangement of institutional and non-institutional credit, account and record keeping etc. were quantified using appropriate procedures. The gender mainstreaming (Daly, 2005; Das et al, 2011) to assess the equity and equality, of the men and women counterparts of the family were separately interviewed to evaluate their access to resources, participation profile, decision making aspect and gender need analysis.

Level of Performance (NABARD, 2007, Shalumol, 2015) of SHG was assessed by the NABARD checklist containing 16 dimensions including group size, type of members, number of meetings, timings of meetings, attendance of members, participation of members, savings collection within the group, amount to be saved, interest on internal loan, utilization of savings amount by SHG, loan recoveries, maintenance of books, accumulated savings, knowledge of the rules of SHG, education level, knowledge of Govt. programs etc. arranged in a 3 point continuum. Similarly, the Empowerment Index was quantified based on 8 dimensions (Meena et al., 2012) such as confidence building, self-esteem, decision making pattern, capacity building, psychological empowerment, social empowerment, economic empowerment and political empowerment. The extent of empowerment was quantified as the difference between the scores obtained as per the perception of the SHG members before and after joining the SHG. For computing the Empowerment Index, the scores obtained for each dimensions were first made uniform and that was multiplied by the weightages assigned by the judges while relevancy rating for ascertaining the content validity of the scale through scale product method. (Vipinkumar and Asokan, 2008. Vipikumar et al., 2017; 2018). Each dimension of Empowerment Index was computed by the scores of subdimensions coming under the categories of these 8 dimensions. Similarly, to find out the statistical difference between the mean empowerment index scores: before and after joining SHG, paired sample $t$ test was conducted separately for different SHGs. Socio-economic, technological and export support requirements were also analyzed for gender mainstreaming. Male and female respondents in a household were separately interviewed for getting the response of gender needs in terms of access to resources.

\section{Results and discussion}

\section{Empowerment Index and Level of Performance of SHGs}

The Empowerment Index and Level of Performance of two SHGs namely Amma seafood kitchen unit and Theeramythri seafood kitchen unit were quantified and presented in Table 1. Paired sample t test was conducted separately for different SHGs to find out the statistical difference between the mean

Table 1. Empowerment Index components and level of performance of SHGs

\begin{tabular}{lll}
\hline Parameters & $\begin{array}{l}\text { Amma seafood kitchen } \\
\text { SHG, Poyya, Thrissur }\end{array}$ & $\begin{array}{l}\text { Theeramythri seafood kitchen } \\
\text { SHG, Pookode, Wayanadu }\end{array}$ \\
\hline Confidence building & 0.798 & 0.685 \\
\hline Self esteem & 0.781 & 0.636 \\
\hline Decision making Pattern & 0.708 & 0.702 \\
\hline Capacity building & 0.762 & 0.692 \\
\hline Psychological empowerment & 0.780 & 0.643 \\
\hline Social empowerment & 0.782 & 0.729 \\
\hline Economic empowerment & 0.793 & 0.735 \\
\hline Political empowerment & 0.738 & 0.713 \\
\hline Overall Empowerment Index & 0.768 & 0.692 \\
\hline Level of Performance & 67 per cent & 60 per cent \\
\hline
\end{tabular}


Table 2. Impact of SHGs on women empowerment using Paired t test

\begin{tabular}{|c|c|c|c|c|c|c|}
\hline \multirow{3}{*}{ Empowerment dimensions } & \multicolumn{3}{|c|}{ SHG 1:Amma seafood kitchen, Poyya, Thrissur } & \multicolumn{3}{|c|}{ SHG 2: Theeramythri Seafood kitchen, Pookode, Wayanadu } \\
\hline & \multicolumn{2}{|c|}{ Average Empowerment Index } & \multirow[t]{2}{*}{ t value } & \multicolumn{2}{|c|}{ Average Empowerment Index } & \multirow[t]{2}{*}{ t value } \\
\hline & Before & After & & Before & After & \\
\hline Confidence building & 0.338 & 0.798 & 43.26 & 0.340 & 0.685 & 41.86 \\
\hline Self esteem & 0.346 & 0.781 & 52.86 & 0.348 & 0.636 & 36.27 \\
\hline Decision making Pattern & 0.372 & 0.708 & 42.76 & 0.367 & 0.702 & 41.76 \\
\hline Capacity building & 0.324 & 0.762 & 32.48 & 0.318 & 0.692 & 31.88 \\
\hline Psychological empowerment & 0.272 & 0.780 & 19.68 & 0.323 & 0.643 & 16.24 \\
\hline Social empowerment & 0.345 & 0.782 & 54.48 & 0.333 & 0.729 & 40.38 \\
\hline Economic empowerment & 0.342 & 0.793 & 41.08 & 0.296 & 0.735 & 27.78 \\
\hline Political empowerment & 0.301 & 0.738 & 13.49 & 0.258 & 0.713 & 14.86 \\
\hline
\end{tabular}

Note: All the $p$ values in the t-test were found to be significant at $1 \%$ level.

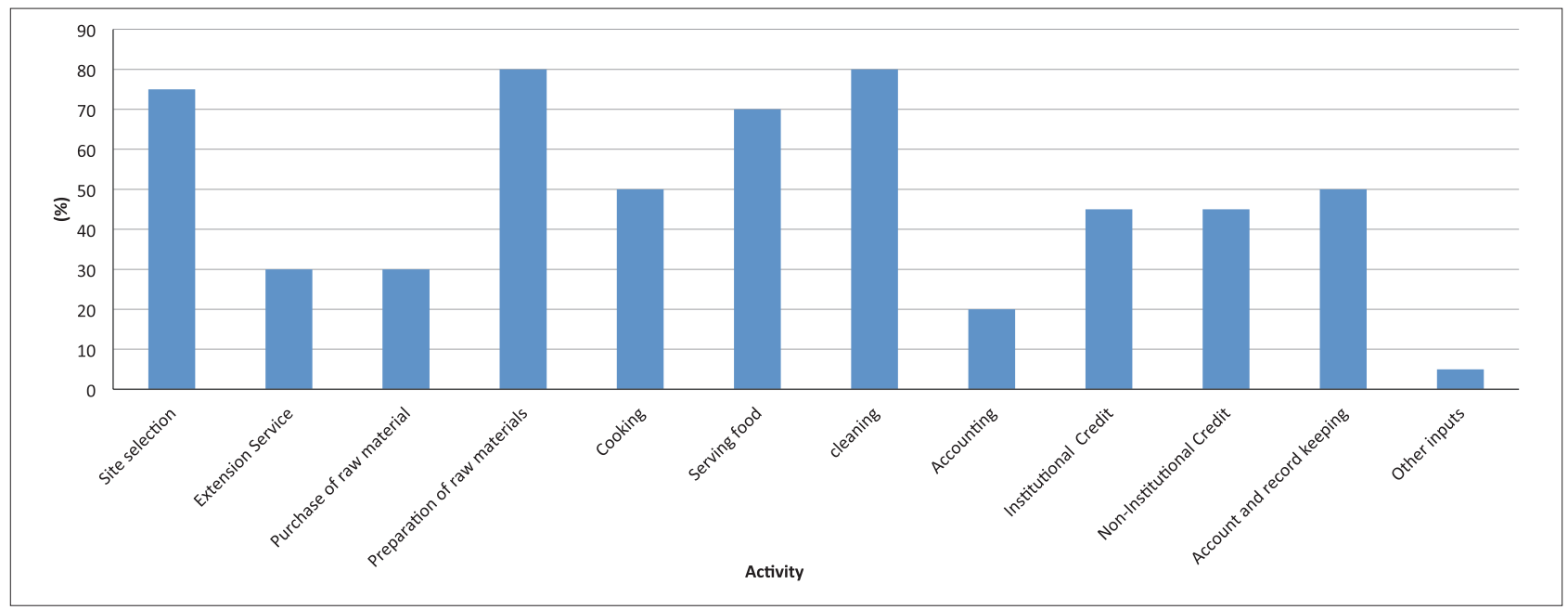

Fig. 2. Extent of involvement in Entrepreneurial Activity $(n=23)$

empowerment index scores: before and after joining SHG. The results of the paired sample $t$ test given in Table 2 were highly significant $(p<0.01)$ in all the eight empowerment variables considered for the present study, indicating that there was a significant increase in the empowerment scores before and after the formation of SHG. The extent of involvement in various phases of the entrepreneurial activity was also quantified and expressed in Fig. 2. Maximum participation of the members and families was observed during site selection and marketing stages.

\section{Participation Profile, Access to resources, Gender Need analysis and Decision making}

The extent of involvement of SHG members in various phases of the Entrepreneurial Activity was also quantified and expressed in Fig. 2. Maximum participation of the members and families was observed during site selection and arrangements of inputs stages.
An assessment of gender perspectives in terms of gender need and gender role in the running of hotel was also done as a part of the study. All households were selected and male and female counterparts in each household were separately interviewed. Gender participation in different activities, gender needs, decision making and access and control over the resources in respect to hotel running were analyzed and the opinion of men and women in the above aspect was found to be similar without any significant difference. However, differential gender response was observed among SHGs. Significantly, the accounting/ money transaction is under the control of women and the most important requirement perceived by both men and women is cooking. In case of participation and need, both men and women share almost the same opinion. (Sahoo et al, 2009, Raghavan, 2009). Socio-economic, technological and export support requirements were analyzed for gender mainstreaming. Male and female respondents in a household were separately interviewed for getting the response of gender needs in terms 
Table 3. Access to resources for seafood unit

\begin{tabular}{|c|c|c|c|c|c|c|c|c|c|c|c|c|}
\hline \multirow{3}{*}{ Resource Access } & \multicolumn{8}{|c|}{ Female } & \multirow{2}{*}{\multicolumn{2}{|c|}{$\begin{array}{l}\text { Male } \\
\text { Alone }\end{array}$}} & \multirow{2}{*}{\multicolumn{2}{|c|}{$\begin{array}{l}\text { No } \\
\text { Access }\end{array}$}} \\
\hline & \multicolumn{2}{|l|}{ Alone } & \multicolumn{2}{|c|}{$M<F$} & \multicolumn{2}{|l|}{$M=F$} & \multicolumn{2}{|c|}{$M>F$} & & & & \\
\hline & $\mathrm{F}$ & M & $\mathrm{F}$ & M & $\mathrm{F}$ & M & $\mathrm{F}$ & M & $\mathrm{F}$ & M & $\mathrm{F}$ & M \\
\hline Site selection & 66.67 & 50 & 0 & 0 & 33.33 & 50 & 0 & 0 & 0 & 0 & 0 & 0 \\
\hline Extension Service & 100 & 100 & 0 & 0 & 0 & 0 & 0 & 0 & 0 & 0 & 0 & 0 \\
\hline Purchase of raw materia & 50 & 33.33 & 0 & 0 & 50 & 66.67 & 0 & 0 & 0 & 0 & 0 & 0 \\
\hline Preparation of raw materials & 100 & 100 & 0 & 0 & 0 & 0 & 0 & 0 & 0 & 0 & 0 & 0 \\
\hline Cooking & 100 & 100 & 0 & 0 & 0 & 0 & 0 & 0 & 0 & 0 & 0 & 0 \\
\hline Serving food & 100 & 100 & 0 & 0 & 0 & 0 & 0 & 0 & 0 & 0 & 0 & 0 \\
\hline cleaning & 100 & 100 & 0 & 0 & 0 & 0 & 0 & 0 & 0 & 0 & 0 & 0 \\
\hline Accounting & 100 & 100 & 0 & 0 & 0 & 0 & 0 & 0 & 0 & 0 & 0 & 0 \\
\hline Institutional Credit & 100 & 100 & 0 & 0 & 0 & 0 & 0 & 0 & 0 & 0 & 0 & 0 \\
\hline Non-Institutional Credit & 100 & 100 & 0 & 0 & 0 & 0 & 0 & 0 & 0 & 0 & 0 & 0 \\
\hline Account and record keeping & 100 & 100 & 0 & 0 & 0 & 0 & 0 & 0 & 0 & 0 & 0 & 0 \\
\hline Other inputs & 33.33 & 50 & 0 & 0 & 66.67 & 50 & 0 & 0 & 0 & 0 & 0 & 0 \\
\hline
\end{tabular}

\begin{tabular}{|c|c|c|c|c|c|c|}
\hline \multirow[b]{2}{*}{ Activity } & \multicolumn{2}{|c|}{ Man (Independently) } & \multicolumn{2}{|c|}{ Men and women together } & \multicolumn{2}{|c|}{ Women (Independently) } \\
\hline & Female & Male & Female & Male & Female & Male \\
\hline Site selection & 0.00 & 0.00 & 33.33 & 50.00 & 66.67 & 50.00 \\
\hline Extension Service & 0.00 & 0.00 & 0.00 & 0.00 & 100.00 & 100.00 \\
\hline Purchase of raw material & 0.00 & 0.00 & 16.67 & 50.00 & 83.33 & 16.67 \\
\hline Preparation of raw materials & 0.00 & 0.00 & 0.00 & 0.00 & 100.00 & 100.00 \\
\hline Cooking & 0.00 & 0.00 & 0.00 & 0.00 & 100.00 & 100.00 \\
\hline Serving food & 0.00 & 0.00 & 0.00 & 0.00 & 100.00 & 100.00 \\
\hline cleaning & 0.00 & 0.00 & 0.00 & 0.00 & 100.00 & 100.00 \\
\hline Accounting & 0.00 & 0.00 & 0.00 & 0.00 & 100.00 & 100.00 \\
\hline Institutional Credit & 0.00 & 0.00 & 0.00 & 0.00 & 100.00 & 100.00 \\
\hline Non- Institutional Credit & 0.00 & 0.00 & 0.00 & 0.00 & 100.00 & 100.00 \\
\hline Account and record keeping & 0.00 & 0.00 & 0.00 & 0.00 & 100.00 & 100.00 \\
\hline Other inputs & 0.00 & 0.00 & 50.00 & 33.33 & 50.00 & 66.67 \\
\hline
\end{tabular}

Table 5. Gender needs in activities of seafood kitchen unit

\begin{tabular}{lllllll}
\hline Need Area & \multicolumn{2}{l}{ Important } & \multicolumn{2}{l}{ More Important } & \multicolumn{2}{l}{ Most Important } \\
\hline & Female & Male & Female & Male & Female & Male \\
\hline Site selection & 100 & 100 & 0 & 0 & 0 & 0 \\
\hline Extension Service & 100 & 100 & 0 & 0 & 0 & 0 \\
\hline Purchase of raw & 0 & 0 & 100 & 100 & 0 & 0 \\
\hline material Preparation of raw & 33.33 & 50 & 50 & 16.67 & 16.67 & 33.33 \\
\hline materials Cooking & 0 & 0 & 0 & 0 & 100 & 100 \\
\hline Serving food & 50 & 100 & 50 & 0 & 0 & 0 \\
\hline cleaning & 0 & 0 & 50 & 66.67 & 50 & 33.33 \\
\hline Accounting & 100 & 100 & 0 & 0 & 0 & 0 \\
\hline Institutional & 100 & 100 & 0 & 0 & 0 & 0 \\
\hline Credit Non-Institutional & 100 & 100 & 0 & 0 & 0 & 0 \\
\hline Credit Account and & 100 & 100 & 0 & 0 & 0 & 0 \\
\hline record keeping Other inputs & 100 & 100 & 0 & 0 & 0 & 0 \\
\hline
\end{tabular}

of access to resources in hotel management, participation in various activities of running a hotel, gender needs and decision making in various stages. The typology of access to resources in running a sea food kitchen in gender response such as female alone, male $<$ female, male $=$ female, male $>$ female and male alone indicated separately for male and female respondents.

A perusal of table 3 clearly shows the response of male and female separately in access to resources concerned with running a hotel. Among the responses of female and male for the items of access to resources, most of the items are dominated by 'female alone'.

Similarly, the participation profile in various activities concerned with seafood kitchen is presented in a Table 4. The gender response in participation in various activities such as female alone, male $<$ female, male $=$ female, male $>$ female and male alone indicated separately by male and female are presented. A perusal of the table clearly indicates the 
Table 6. Decision making in various phases of seafood Unit

\begin{tabular}{|c|c|c|c|c|c|c|c|c|c|c|}
\hline \multirow{2}{*}{ Activity } & \multicolumn{2}{|c|}{ Female Alone } & \multicolumn{2}{|c|}{$\mathrm{M}<\mathrm{F}$} & \multicolumn{2}{|c|}{$M=F$} & \multicolumn{2}{|c|}{$M>F$} & \multicolumn{2}{|c|}{ Male Alone } \\
\hline & $\mathrm{F}$ & M & $\mathrm{F}$ & M & $\mathrm{F}$ & $M$ & $\mathrm{~F}$ & $M$ & $\mathrm{~F}$ & $M$ \\
\hline Site selection & 100 & 100 & 0 & 0 & 0 & 0 & 0 & 0 & 0 & 0 \\
\hline Extension Service & 100 & 100 & 0 & 0 & 0 & 0 & 0 & 0 & 0 & 0 \\
\hline Purchase of raw material & 50 & 33.33 & 0 & 0 & 50 & 66.67 & 0 & 0 & 0 & 0 \\
\hline Preparation of raw materials & 100 & 100 & 0 & 0 & 0 & 0 & 0 & 0 & 0 & 0 \\
\hline Cooking & 100 & 100 & 0 & 0 & 0 & 0 & 0 & 0 & 0 & 0 \\
\hline Serving food & 100 & 100 & 0 & 0 & 0 & 0 & 0 & 0 & 0 & 0 \\
\hline cleaning & 100 & 100 & 0 & 0 & 0 & 0 & 0 & 0 & 0 & 0 \\
\hline Accounting & 100 & 100 & 0 & 0 & 0 & 0 & 0 & 0 & 0 & 0 \\
\hline Institutional Credit & 100 & 100 & 0 & 0 & 0 & 0 & 0 & 0 & 0 & 0 \\
\hline Non-Institutional Credit & 100 & 100 & 0 & 0 & 0 & 0 & 0 & 0 & 0 & 0 \\
\hline Account and record keeping & 100 & 100 & 0 & 0 & 0 & 0 & 0 & 0 & 0 & 0 \\
\hline Other inputs & 33.33 & 33.33 & 0 & 0 & 66.67 & 66.67 & 0 & 0 & 0 & 0 \\
\hline
\end{tabular}

participation profile in gender perspective for male and female separately. It can be seen clearly from the table that, most of the activities are female dominating operations in running the hotel, as per the responses of both male and female. But the site selection and marketing activities are performed by both men and women.

In the same way, response to gender needs in various activities concerned with running a cafeteria, as per the importance assigned by male and female separately is presented in Table 5 .

With regard to gender needs, the most important need area expressed by both male and female counterparts includes cooking and cleaning. Cooking of food items is the key for success of the dynamics of the SHG. Proper training on technical matters and marketing aspects is inevitable for desirable results. Decision making in various phases is presented in Table 6.

The economic feasibility analysis of a typical seafood kitchen unit was also done representing the indicative economics and results of the data gathered on 'Amma seafood kitchen unit in Poyya' and are presented in Table 7 pointing out the cost and return streams.

The average operating cost for Amma Seafood was Rs. 18,10,788/and average annual net return was found to be Rs. 9,23,772/-. The total fixed cost was estimated to be Rs 380800/-. The fixed cost was incurred only in the first year. The Break Even Point (BEP) (Fixed cost/ (Price per unit-Variable cost per unit) was estimated to be 34,618 (number of visitors to seafood kitchen

Table 7. Economic feasibility analysis of seafood kitchen unit cost stream return stream

\begin{tabular}{|c|c|c|c|c|c|c|c|c|}
\hline Items & Units & Value in Rs. & Units & Value in Rs. & Units & Value in Rs. & Units & Value in Rs. \\
\hline Fish curry meals & 9000 & 540000 & 12000 & 720000 & 13500 & 810000 & 14150 & 849000 \\
\hline Sea food & 8300 & 415000 & 9000 & 450000 & 9200 & 460000 & 9320 & 466000 \\
\hline Beef & 8100 & 364500 & 9000 & 405000 & 8950 & 402750 & 9160 & 412200 \\
\hline Chicken & 6250 & 343750 & 7500 & 412500 & 7860 & 432300 & 7950 & 437250 \\
\hline Breakfast Items & 7950 & 238500 & 10500 & 315000 & 10800 & 324000 & 10930 & 327900 \\
\hline Veg/egg curry & 7950 & 238500 & 10500 & 315000 & 10800 & 324000 & 10930 & 327900 \\
\hline Snacks & 8300 & 58100 & 10500 & 73500 & 10980 & 76860 & 11250 & 78750 \\
\hline Hot beverages & 7650 & 61200 & 9000 & 72000 & 9700 & 77600 & 9850 & 78800 \\
\hline Sweets & 4900 & 24500 & 6000 & 30000 & 5400 & 27000 & 5200 & 26000 \\
\hline Cold & 4100 & 49200 & 4500 & 54000 & 5100 & 61200 & 5260 & 63120 \\
\hline Gross Return (Rs.) & & 2333250 & & 2847000 & & 2995710 & & 3066920 \\
\hline Net Returns (Rs.) & & 548260 & & 1033030 & & 1040540 & & 1073260 \\
\hline Fixed Expenditure & & 2013 & & 2014 & & 2015 & & 2016 \\
\hline
\end{tabular}




\begin{tabular}{|c|c|c|c|c|c|c|c|}
\hline Items & Units & Value in Rs. & Units & Value in Rs. & Units & Value in Rs. & Value in Rs. \\
\hline Two burner stove & 1 & 22000 & & & & & \\
\hline Cooking Range & 2 & 28000 & & & & & \\
\hline \multicolumn{8}{|l|}{ Ss work table and } \\
\hline $\operatorname{rack}(5)$ & 1 & 44000 & & & & & \\
\hline Three Sink unit & 1 & 23000 & & & & & \\
\hline Refrigerator & 1 & 15500 & & & & & \\
\hline Wet grinder & 1 & 21000 & & & & & \\
\hline Exhaust Fan & 1 & 6000 & & & & & \\
\hline Freezer with glass top & 1 & 17400 & & & & & \\
\hline Furniture & & 90950 & & & & & \\
\hline Thermal printer & 1 & 14000 & & & & & \\
\hline Utensils and Service wares & & 98950 & & & & & \\
\hline Provision items, Fish, Meat, Vegetables, Milk & & 750000 & & 775810 & & 911010 & 944600 \\
\hline Fixed Assets & & 380800 & & & & & \\
\hline \multicolumn{8}{|l|}{ Variable Expenditure } \\
\hline Labour charge (Rs.2400 for 300 man days) & & 720000 & & 720000 & & 720000 & 720000 \\
\hline LPG & & 17830 & & 20900 & & 24300 & 26100 \\
\hline Firewood & & 23000 & & 22500 & & 23800 & 2300 \\
\hline Current charge (Rs.3000/month) & & 36000 & & 36000 & & 36000 & 36000 \\
\hline Rent (Rs.2500/month) & & 30000 & & 30000 & & 30000 & 30000 \\
\hline Transportation & & 48000 & & 48000 & & 48000 & 48000 \\
\hline Telephone & & 12000 & & 14000 & & 14500 & 14500 \\
\hline Water charge & & 5000 & & 5000 & & 5000 & 6100 \\
\hline Packing materials & & 26000 & & 29600 & & 30400 & 33200 \\
\hline Office stationary & & 29000 & & 24000 & & 24000 & 24000 \\
\hline Miscellaneous & & 12000 & & 12000 & & 12000 & 12000 \\
\hline Operating Cost (Rs.) & & 1708830 & & 1737810 & & 1879010 & 1917500 \\
\hline Interest on fixed cost ( $10 \%$ /annum) & & 38080 & & 38080 & & 38080 & 38080 \\
\hline Deprecation (10\%/annum) & & 38080 & & 38080 & & 38080 & 38080 \\
\hline Total Variable Cost(Rs.) & & 1784990 & & 1813970 & & 1955170 & 1993660 \\
\hline
\end{tabular}

units) and the Pay Back Period assessment indicates that, the event takes 3 years to break even.

An assessment of the seafood kitchens brought out a couple of valid conclusions as, it was understood that, the female counterparts also do have a definite role in site selection, purchase of accessories, cooking, serving, cleaning, marketing etc. The Scales of 'Performance Assessment' and 'Empowerment Index' developed for this study have good potential for future use in other key areas on a sustainable basis. Lacunae identified in Empowerment Index computation give adequate feedback to authorities to proceed in the right direction. The gender dimension analysis on mainstreaming aspect gives sensitization on crucial issues like women fisher folk's rights and marketing channels for policies and other interventions on gender.
An exhaustive research with larger sample and wider area would be of ample scope. Interrelationships between the variables can act as catalytic points for group action and group empowerment on a sustainable basis. Success case study elucidated and brought out as video documentary entitled 'Women SHGs in Seafood kitchen: A Striking Success Story in Poyya and Pookode' which has already been put in the institute repository often referred by the needy is being used as a practical manual for mobilizing SHGs on a sustainable basis.

\section{Acknowledgements}

The authors thank immensely the Director, ICAR-CMFRI, Dr. A. Gopalakrishnan, Smt. C. R. Sathiavathy, Joint Director, 


\section{SAF, Kerala State other SAF officials and SHG members for the wholehearted cooperation rendered to undertake the research study.}

\section{References}

Daly, M. 2005. Gender mainstreaming in theory and practice, Social Politics: International Studies in Gender, State \& Society, 12(3): 433-450.

Das, B. K., B. C. Mohapatra, De, H. K. Chattopadhay, D. N. Sarangi, A. E. Eknath, S. Chandra, P. Pattanaik, A. Mallick, D. K. Swain and S. Ghosh. 2011. Women Self Help Group in Aquaculture at Tanar, Kendrapada Sadar, Orissa - a Case Study. In: Radheyshyam, Saha, G. S. and De, H. K. (Eds.), Aquaculture Innovators. Central Institute of Freshwater Aquaculture, Bhubaneswar, India. p. 78-86.

FA0. 2017. Towards gender-equitable small-scale fisheries governance and development-A handbook. In support of the implementation of the Voluntary Guidelines for Securing SustainableSmall-Scale Fisheries in the Context of Food Security and Poverty Eradication, by Nilanjana Biswas. Rome, Italy. 174p.

Meena. M. L., Dheeraj Singh and Aiswarya Dudi. 2012. Role Perception about Empowerment of Farm Women in Agriculture in Western Rajasthan. Asian J. Home Sci., 7 (2): 237-241.

NABARD, 2007. SHG Bank linkage programme, status as on March 31 2007, NABARD, Mumbai.

Raghavan, V. P. 2009. Micro-credit and Empowerment: a study of Kudumbashree Projects in Kerala. Ind. J. Rural Dev., 28:478-479.

Shalumol, S. 2015. Women empowerment through entrepreneurial activities of fishery based Self Help Groups in Kerala. Unpublished M.F. Sc. Thesis, CIFE, Mumbai. 81 pp.
Sahoo, P. K., V. P. Vipinkumar, A. K. Mishra and M. Srinath. 2009. Gender Participation and Gender Issues in Mussel Culture- A Study from Coastal Village of Kerala. (Abstract) In Compilation of Abstracts of National Seminar on Women in Agriculture organized by International Extension Forum (IEF), Directorate of Research on Women in Agriculture (DRWA) and Research Association for Gender in Agriculture (RAGA), Bhubaneswar. p 25.

Vipinkumar. V. P. and P. K. Asokan. 2008. Mussel Farming Technology Dissemination to the Self Help Groups. Ind. J. Extn. Educ., 44 (1 \& 2): 112-115.

Vipinkumar, V. P., R. Narayanakumar, N. K. Harshan, Jephi Annmary, T. J. Jeethumol and D. Dilip. 2017. Impact of Self Help Groups in Gender Mainstreaming: A Case Study on Fish Amino Enterprise in Vypin, Kerala. Int. J. Pure. Appl. Biosci., 5 (6): 337-345.

Vipinkumar, V. P., R. Narayanakumar, N. K. Harshan, P. V. Sunil, Jephi Annmary, P. V. Athira, T. V. Ambrose and T. J. Jeethumol. 2017. Mainstreaming gender through Aquatourism venture: an assessment of impact of women SHGs in Kerala. Discovery Nature, 11(26): 1-19.

Vipinkumar, V. P., K. Thomas Ajith, R. Narayanakumar, N. K. Harshan, P. V. Sunil, Jephi Annmary, P. Dona, Salas Shalumol, P. V. Athira and D. Dilip. 2018. Gender mainstreaming and Impact of Self Help Groups: A Study on Socia Entrepreneurship through Fish Aggregating Devices in Mannancheri of Alappuzha, Kerala. Int. J. Pure Appl. Biosc., 6(2):74-83. doi: http://dx.doi. org/10.18782/2320-7051.6385

Vipinkumar, V. P., R. Narayanakumar, R. Vidya, P. Shinoj, N. K. Harshan, P. V. Athira, T. J. Jeethumol, and Jephy Annmary. 2017. Impact of Self Help Groups in Gender Mainstreaming: A Case Study on Clam processing units in Pookaitha village, Kottayam, Kerala. J. Mar. Biol. Ass. India, 59(2):19-25. 